\title{
Angling records track the near extirpation of angel shark Squatina squatina from two Irish hotspots
}

\author{
Samuel Shephard ${ }^{1, *}$, Ciara Wögerbauer ${ }^{1}$, Peter Green $^{1}{ }^{1}$ Jim R. Ellis ${ }^{2}$, \\ William K. Roche ${ }^{1}$ \\ ${ }^{1}$ Inland Fisheries Ireland, 3044 Lake Drive, Citywest Business Campus, Dublin D24 Y265, Ireland \\ ${ }^{2}$ Centre for Environment, Fisheries and Aquaculture Science, Lowestoft Laboratory, Pakefield Road, Lowestoft, \\ Suffolk NR33 0HT, UK
}

\begin{abstract}
The angel shark Squatina squatina was historically common in coastal waters from the British Isles to north-western Africa, including the Mediterranean. Reported commercial landings from northern Europe reduced to near-zero before the species was added to the EU Prohibited Species list and subsequently listed as Critically Endangered by the IUCN. S. squatina is encountered rarely in offshore trawl surveys, probably because of low spatial overlap with coastal populations and habitats. An alternative source of monitoring data is angling vessels, which can operate in discrete inshore areas. Analyses of 2 unique $>40 \mathrm{yr}$ time series of angler tagging and specimen catch data from Irish waters, with catch and effort records from voluntary charter angling logbooks, reveal a sharp decline in S. squatina catches. Only 1 individual has been tagged since 2011. Almost all reports were from Tralee Bay and Clew Bay (western Ireland), where anecdotal sightings still occur. These historical hotspots may be significant to international angel shark conservation efforts.
\end{abstract}

KEY WORDS: IUCN Red List · Overfishing $\cdot$ Bycatch $\cdot$ Elasmobranchs $\cdot$ Skates and rays $\cdot$ Marine Protected Areas

\section{INTRODUCTION}

The common angel shark Squatina squatina was historically abundant across a geographic range (Fig. 1) extending from Ireland, Britain and southern Scandinavia to north-western Africa, including the Mediterranean Sea (Roux 1984). Analyses of trawl survey data from British coastal waters record a strong decline in abundance over the 20th century (Rogers \& Ellis 2000), and $S$. squatina is now largely extirpated from the North Sea (ICES 2008a) and the Celtic Seas (ICES 2008b). The loss of S. squatina has also been documented for the Bay of Biscay and parts

\footnotetext{
*Corresponding author: sam.shephard@fisheriesireland.ie
}

of the Mediterranean (Quéro \& Cendrero 1996, Psomadakis et al. 2009). Whilst the Canary Islands now seem to be a remaining global hotspot for $S$. squatina (Meyers et al. 2017), occasional records indicate that small populations persist elsewhere, including the Adriatic (Fortibuoni et al. 2016) and Turkish waters (Kabasakal \& Kabasakal 2014). S. squatina is listed as Critically Endangered by the IUCN (Ferretti et al. 2015) and is included in the Oslo and Paris Conventions List of Threatened and Declining Species (OSPAR Commission 2010). In 2017, it was listed in Appendices I and II of the Convention on Migratory Species (CMS).

(C) The authors 2019. Open Access under Creative Commons by Attribution Licence. Use, distribution and reproduction are unrestricted. Authors and original publication must be credited.

Publisher: Inter-Research · www.int-res.com 


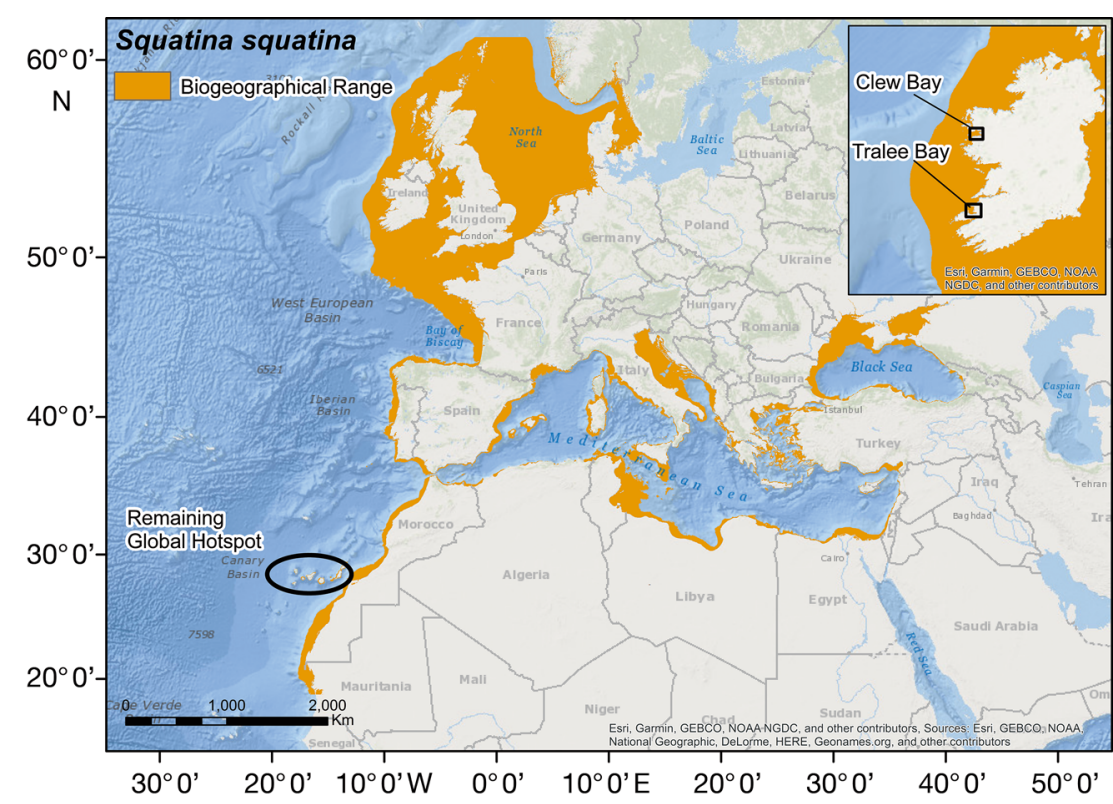

Fig. 1. Biogeographical range of Squatina squatina, showing the locations of Tralee and Clew Bays, Ireland. This map is based on the GEBCO_2014 Grid, version 20150318, www.gebco.net

Observed declines in $S$. squatina are assumed to reflect fishing mortality - predominately as commercial bycatch. This species is vulnerable due to its large size (Dulvy \& Reynolds 2002), coastal habitat and 'slow' life history (Dulvy et al. 2014). Some rod-caught $S$. squatina were retained historically, but angling is now voluntary catch-andrelease. The mortality rate for released elasmobranchs varies among species (Gallagher et al. 2017). Reported commercial landings of $S$. squatina in European Union (EU) Atlantic waters declined steadily prior to its listing as a prohibited species in 2009. Species prohibited under the EU Common Fisheries Policy may not be targeted, retained or landed, and there have been no recorded commercial landings of $S$. squatina in northern Europe since 2011 (ICES 2017). S. squatina is encountered rarely in fishery-independent trawl surveys (Martin et al. 2010); there is low spatial overlap between offshore research survey locations and coastal populations and habitats. It is unlikely that such surveys have the statistical power to detect change in angel shark populations (Maxwell \& Jennings 2005). ICES (2017) recommends non-destructive inshore surveys as a tool for monitoring this species. A possible alternative data source is angling vessels, which exploit many of the inshore areas where refuge populations of $S$. squatina are expected to occur.
Recreational fishing records can be used to discern population trends relevant to fisheries management (Gartside et al. 1999), and can be an important citizen science contribution (Gledhill et al. 2015, Näslund \& Lundgren 2018). There are 2 programmes which record angling captures of notable fish in Irish waters. The Irish Specimen Fish Committee (ISFC) was founded in 1955 to verify and record rod and line captures of large fish, and requires verified length/weight and species identification. A list of 'specimen' captures is published annually (http://irish-trophyfish.com/). The Irish Marine Sportfish Tagging programme (IMST) was initiated in 1970 in collaboration with many charter and private angling vessels. The IMST aimed to encourage catch-and-release as a conservation measure and to investigate the movements and migratory patterns of target species, primarily elasmobranchs.

The majority of $S$. squatina recorded as specimens (ISFC) or tagged (IMST) were caught in Tralee Bay (southwest Ireland, Fig. 1). Tralee Bay is an EU Special Area of Conservation (SAC) and Natura 2000 site, although $S$. squatina is not a defining species for designating this site. It is a sheltered site, with shallow sandy habitat suitable for $S$. squatina (Meyers et al. 2017). A secondary location was Clew Bay (western Ireland, Fig. 1). Both bays are known to be historically important habitats for several skate species (Went 1978, Fahy \& O'Reilly 1990), but very few $S$. squatina have been recorded in recent years. Records from the IMST and the ISFC were combined with voluntary charter skipper logbook data to investigate trends in abundance and size structure of S. squatina in Tralee and Clew Bays since 1958. The objective was to highlight the current status of $S$. squatina in 2 historical hotspots and to inform conservation efforts.

\section{MATERIALS AND METHODS}

The analysis was based on angling records that extend back to the 1950s. These data show consistent patterns of seasonal effort and reporting that reveal long-term trends. There is insufficient information on exact angling location, bait, etc. to support analyses of possible fine-scale bias in these factors. 


\subsection{Tagging records}

The tagging programme distributes numbered tags to volunteer skippers, together with instructions and a logbook to record relevant information (tag number, species, length and weight, location, date, etc.). Tags have the instruction 'Fisheries Board Ireland Reward' printed in English (the reward being a cap with a fishing logo). Specimens of Squatina squatina were tagged with 'Jumbo tags' (Dalton Tags), a 2piece cattle ear tag that is inserted through the posterior edge of the dorsal fin. Jumbo tags are applied while on-board the vessel to ensure a secure fix to the fish prior to release. S. squatina were tagged from the inaugural year of the programme in 1970.

\subsection{Specimen fish}

Specimen fish caught in Irish waters are reported with information on date of capture, location and fish size. Historically, some species were retained, but the majority are now typically released. $S$. squatina (specimen threshold weight $\geq 22.68 \mathrm{~kg}$ ) were recorded consistently by the ISFC from 1958-2002; the species was removed from the list in 2006 in order to promote live release. In 2016, $S$. squatina was restored to the list of eligible species (with a specimen length threshold only) to support data collection, but none have been reported.

\subsection{Skipper logbooks}

Anonymized logbook data were collated for some of the most active charter angling vessels in Tralee Bay, where reporting for each boat was predominately by the same skipper. Logbooks recorded the number of angler rod days (targeting demersal species) and the number of S. squatina captured (1979 to 2006).

\subsection{Time-series plots}

Summary time-series plots were produced to illustrate temporal changes in $S$. squatina populations in Irish waters:
1. Numbers caught in Tralee and Clew Bays

2. Catch and effort for charter skippers operating in Tralee Bay

3. Fish lengths by location for specimen and tagging records.

Patterns in each time series were qualitatively evaluated.

\section{RESULTS}

\subsection{Number of fish}

Between 1958 and 2006, 1261 Squatina squatina were recorded by the Irish tagging and specimen fish programmes combined. Most individuals (86\%) were captured in Tralee Bay, with a further $9 \%$ captured in Clew Bay. Catches fluctuated over the early years of the programme, with few records around 1970. This low period may reflect a hiatus in angling effort or reporting, but unfortunately this information was not recorded before 1979. The number of $S$. squatina tagged has declined markedly over the last 25 yr (particularly in Tralee Bay). Only 20 individuals have been recorded since 2000, and only 1 since 2011 (Fig. 2).

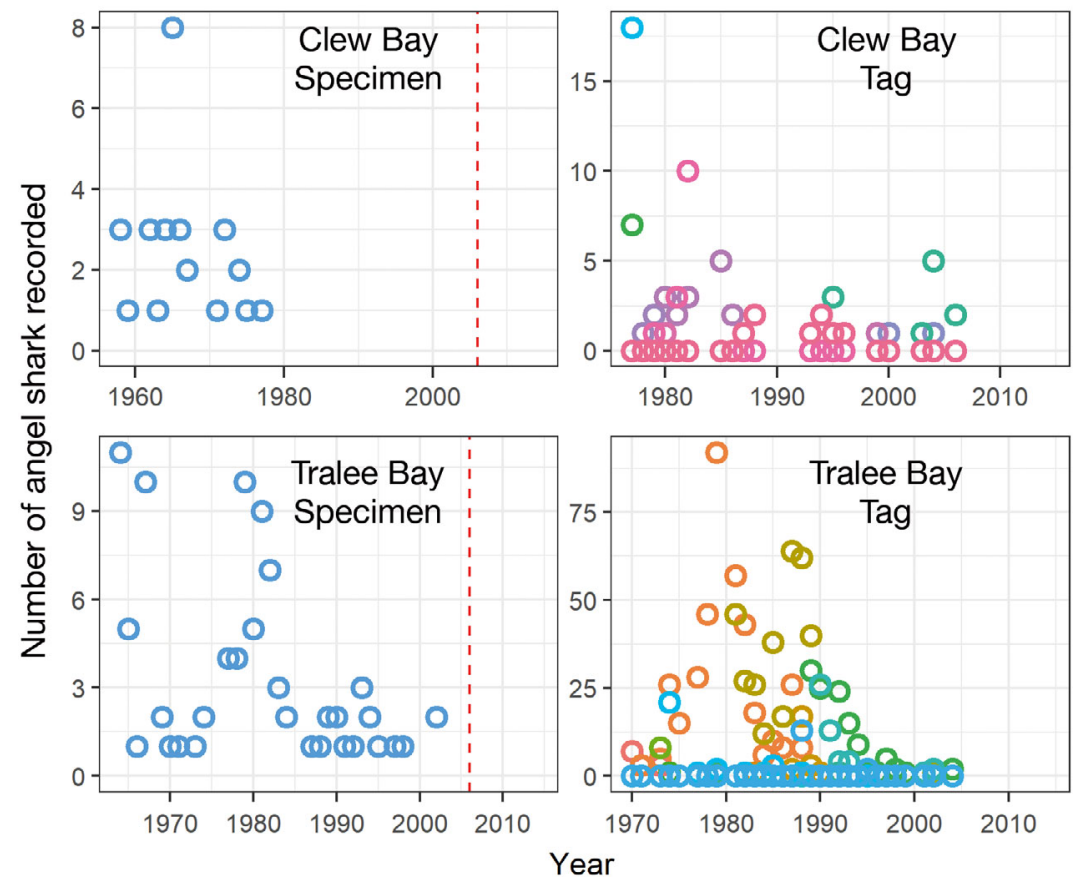

Fig. 2. Records of specimen or tagged Squatina squatina in Clew and Tralee Bays, Ireland. The red vertical line marks the removal of $S$. squatina from the Irish specimen list in 2006. Colours in the tagging plots refer to individual charter angling vessels 


\subsection{Charter vessel catch and effort}

Charter vessel effort declined in Tralee Bay during the early 1980s, and this was associated with reduced catches of $S$. squatina. Effort then stabilised from the late 1980s, when there were 2 large annual catches. There has been a clear collapse in $S$. squatina catch in Tralee Bay since 1990, and this has not been offset by stable or slightly increasing effort after this time (Fig. 3).

\subsection{Length of fish}

There was a general decline in the number of larger specimen $S$. squatina recorded in both study areas over the time series, with this decline occurring earlier in Clew Bay (Fig. 4). There was also a reduction in the number of larger fish being tagged in Tralee Bay (Fig. 5), although some fish in this area were still larger than size at maturity $(128 \mathrm{~cm}$; Capapé et al. 1990). A reduced number of small individuals was also evident in Tralee Bay, hinting at impaired recruitment (Fig. 5). There was no obvious temporal trend in the size of tagged fish in Clew Bay, with 6 large specimens recorded in the latest years, although 2 outlying large fish cannot be seen on the plot (Fig. 5). More male fish $(\mathrm{N}=198)$ than female $(\mathrm{N}=41)$ were recorded in Tralee Bay, with no obvious temporal pattern in sex ratio.
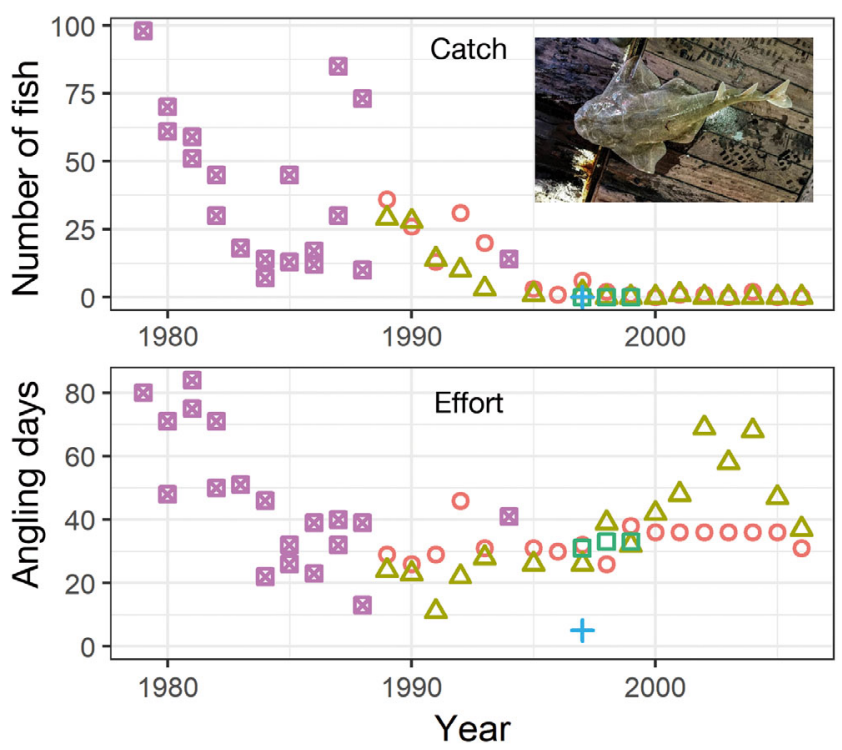

Fig. 3. Squatina squatina annual angling catch and effort for charter vessels in Tralee Bay, Ireland. Inset photograph of $S$. squatina (100 cm total length) caught and released alive from FV 'Eblana' in 2016. Colours of the data points refer to different vessels

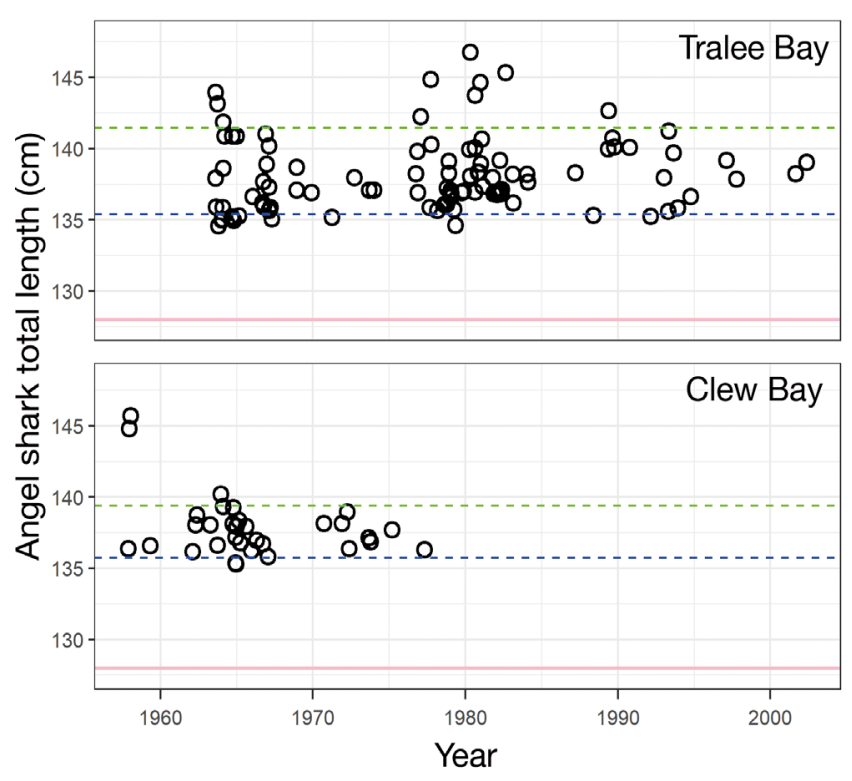

Fig. 4. Lengths of specimen Squatina squatina in Clew and Tralee Bays, Ireland. Blue and green dashed lines are $10^{\text {th }}$ and $90^{\text {th }}$ percentiles of observed length, respectively, by group. The pink line is length at maturity $(128 \mathrm{~cm})$ for female $S$. squatina (Capapé et al. 1990)

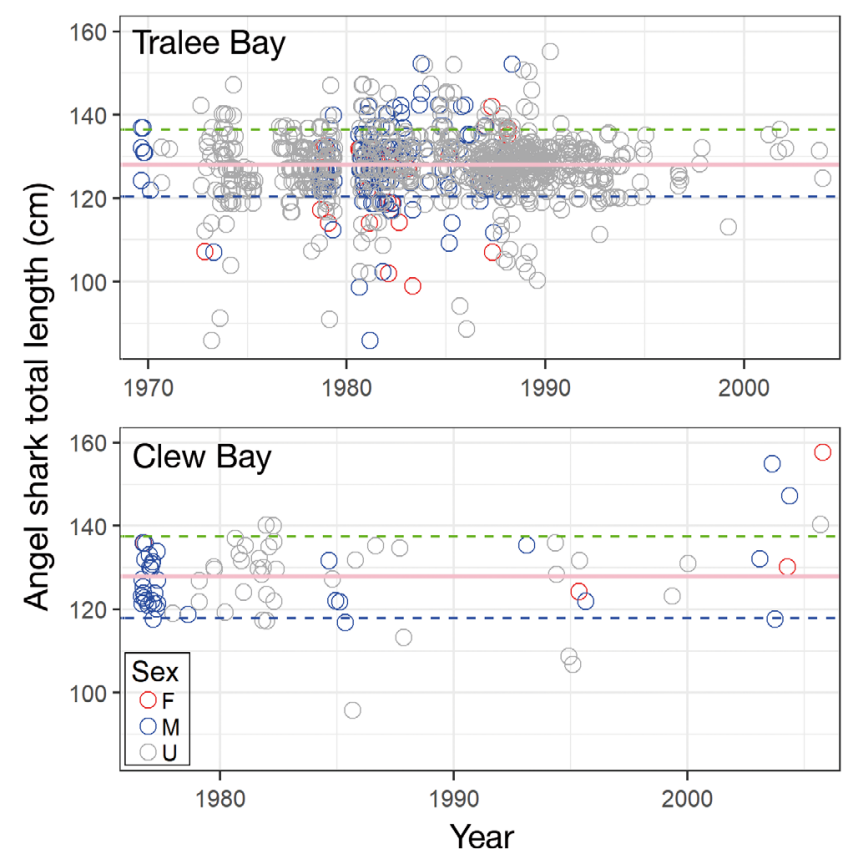

Fig. 5. Lengths of tagged Squatina squatina in Clew and Tralee Bays, Ireland. Blue and green dashed lines are $10^{\text {th }}$ and $90^{\text {th }}$ percentiles of observed length, respectively, by group. The pink line is length at maturity $(128 \mathrm{~cm})$ for female S. Squatina (Capapé et al. 1990). Fish sex is shown, with many individuals unsexed (U). Points are jittered to separate individuals of the same length. The $y$-axis has been adjusted for plotting clarity, resulting in 5 outlying fish not being shown 


\section{DISCUSSION}

Fisheries research surveys may lack the power to detect trends in abundance of rare or inshore marine fishes (Maxwell \& Jennings 2005), and some rarer shark species may not be observed or monitored effectively by observer programmes on commercial vessels (ICES 2017). Angling records can present alternative insight into longer-term abundance and size-structure of these populations (Gartside et al. 1999, Gledhill et al. 2015, Gallagher et al. 2017). Catch and effort data from Irish charter vessels and specimen angling indicated that most Squatina squatina were reported from Tralee and Clew Bays. Catches in these locations remained fairly consistent until around 1990, but subsequently declined to close to zero. The temporal trend in empirical catch is visually similar to the results of a preliminary mark-recapture assessment for the stock, which showed a peak in abundance $(N \approx 1100)$ in 1989 (ICES 2017). Size records for both specimen and tagged fish showed loss of small and large fish in recent years. Critically Endangered $S$. squatina can now be assumed to be extremely rare in both historical hotspots.

The reason for the collapse of $S$. squatina in Tralee and Clew Bays is likely to be a high level of incidental mortality in commercial fisheries, and some historical angling retention. Productivity susceptibility analyses indicate that $S$. squatina is one of the elasmobranch species most vulnerable to demersal trawl and gillnet fisheries (McCully Phillips et al. 2015). Unfortunately, there are few records of commercial catch or bycatch and fishing effort in the inshore fisheries of Tralee and Clew Bays. Impacts on skates in these bays also remain unquantified, and these species may be highly susceptible to fixed bottom-set nets (Baeta et al. 2010). Tangle nets targeting spiny lobster Palinurus elephas and subsequently spider crab Maja squinado were introduced in Tralee Bay in the 1970s (Fox 1985). This fishery has been formally closed since 2002, but there is concern about other on-going fishing pressure on rare and endangered species (BIM 2012).

Some demersal elasmobranchs can benefit from surprisingly small regions of relatively low fishing effort, which represent de facto refugia (Shephard et al. 2012), and such essential habitats may be important to several co-occurring elasmobranchs (SerraPereira et al. 2014). In this context, there may be scope for spatial and/or technical measures for the conservation of possible refuge populations of $S$. squatina in Tralee and Clew Bays. Fine-scale spatialtemporal mapping of their distribution and habitat preference within the bays is now required. Mapping could include a sensitive tagging programme for any extant population(s) and video surveillance (baited remote underwater video systems, BRUVs) (Stat et al. 2019) and may also be facilitated by citizen science via angler/diver reporting smartphone applications such as 'iNaturalist' (https://www.inaturalist.org/).

Currently unavailable spatial information might highlight remaining $S$. squatina hotspots where fishing impacts could be managed. Temporal closures could be used to protect the species during key periods, e.g. the pupping season which occurs around April to July in the Canary Islands (Meyers et al. 2017) and probably requires shallow coastal areas (Vögler et al. 2008). This approach could form the basis of a multi-agency conservation action plan embracing site-specific objectives and special designation, possibly as a marine protected area. Such actions could be supported by anglers, who are increasingly aware of shark conservation issues (Cooke et al. 2016), whilst minimising impacts on inshore fisheries. The Irish marine environment has high economic and cultural value, and for some species anglers appear willing to make sacrifices for sustainable fisheries (Grilli et al. 2017).

The Canary Islands seem to be a remaining hotspot for S. squatina (Meyers et al. 2017), and this has driven the development of the 'Angelshark Action Plan for the Canary Islands' (Barker et al. 2016). This action plan is seen as a key component of the wider Eastern Atlantic and Mediterranean Angel Shark Conservation Strategy, developed to conserve all 3 Critically Endangered angel shark species in the region, including smoothback angelshark Squatina oculata and sawback angelshark Squatina aculeata. Other sites in northern Europe remain potentially important to $S$. squatina, including Tralee and Clew Bays and Cardigan Bay (Wales), where occasional anecdotal (word of mouth) reports still occur. Conservation efforts, including the development of appropriate site management, are required to better understand the current status of $S$. squatina in such areas.

Acknowledgements. Inland Fisheries Ireland (IFI) acknowledges the foresight of those who established the ISFC, the IMST and the voluntary skipper logbook scheme. IFI thanks the charter skipper and private participants.

\section{LITERATURE CITED}

Baeta F, Batista M, Maia A, Costa MJ, Cabral H (2010) Elasmobranch bycatch in a trammel net fishery in the Portuguese west coast. Fish Res 102:123-129 
Barker J, Bartoli A, Clark M, Dulvy NK and others (2016) Angelshark action plan for the Canary Islands. Zoological Society of London, London

BIM (Bord Iascaigh Mhara) (2012) Review of crawfish technical conservation measures. Final report. February 2012. BIM, Dublin. www.bim.ie/media/bim/content/down loads/BIM,Review,of,Crawfish,Technical,Conservation, Measures,Nov2012.pdf

Capapé C, Quignard JP, Mellinger J (1990) Reproduction and development of two angel sharks, Squatina squatina and S. oculata (Pisces: Squatinidae), off Tunisian coasts: semi-delayed vitellogenesis, lack of egg capsules, and lecithotrophy. J Fish Biol 37:347-356

Cooke SJ, Hogan ZS, Butcher PA, Stokesbury MJ and others (2016) Angling for endangered fish: conservation problem or conservation action? Fish Fish 17:249-265

* Dulvy NK, Reynolds JD (2002) Predicting extinction vulnerability in skates. Conserv Biol 16:440-450

Dulvy NK, Fowler SL, Musick JA, Cavanagh RD and others (2014) Extinction risk and conservation of the world's sharks and rays. eLife 3:e00590

Fahy E, O'Reilly R (1990) Distribution patterns of rays (Rajidae: Batoidei) in Irish waters. Ir Nat J 23:316-320

Ferretti F, Morey G, Serena F, Mancusi C, Fowler SL, Dipper F, Ellis J (2015) Squatina squatina. The IUCN Red List of Threatened Species 2015:e.T39332A48933059. www.iucnredlist.org/species/39332/48933059

Fortibuoni T, Borme D, Franceschini G, Giovanardi O, Raicevich S (2016) Common, rare or extirpated? Shifting baselines for common angelshark, Squatina squatina (Elasmobranchii: Squatinidae), in the Northern Adriatic Sea (Mediterranean Sea). Hydrobiologia 772:247-259

Fox P (1985) An investigation of the spider crab resource in Tralee and Brandon Bays - Summer 1985. Resource record note. Mimeo, Bord Iascaigh Mhara, Dublin

Gallagher AJ, Hammerschlag N, Danylchuk AJ, Cooke SJ (2017) Shark recreational fisheries: status, challenges, and research needs. Ambio 46:385-398

Gartside DF, Harrison B, Ryan BL (1999) An evaluation of the use of fishing club records in the management of marine recreational fisheries. Fish Res 41:47-61

Gledhill DC, Hobday AJ, Welch DJ, Sutton SG and others (2015) Collaborative approaches to accessing and utilising historical citizen science data: a case-study with spearfishers from eastern Australia. Mar Freshw Res 66: 195-201

Grilli G, Curtis JA, Hynes S, O'Reilly P (2017) Anglers' views on stock conservation: sea bass angling in Ireland. ESRI Working Paper 578. The Economic and Social Research Institute (ESRI), Dublin

ICES (International Council for the Exploration of the Sea) (2008a) Demersal elasmobranchs in the Celtic Seas (ICES Areas VI, VIIa-c, e-k). ICES Advice 2008, Book 5, Section 5.4.39. ICES, Copenhagen

ICES (2008b) Demersal elasmobranchs in the North Sea (Subarea IV), Skagerrak (Division IIIa), and eastern English Channel (Division VIId). ICES Advice 2008, Book 6, Section 6.4.30, 201-205. ICES, Copenhagen

ICES (2017) Report of the Working Group on Elasmobranchs (2017), 31 May-7 June 2017, Lisbon. ICES CM 2017/ ACOM:16. ICES, Copenhagen

Editorial responsibility: Austin Gallagher,

Herndon, Virginia, USA
Kabasakal H, Kabasakal Ö (2014) Status of angelshark, Squatina squatina (Elasmobranchii: Squatiniformes: Squatinidae) in the Sea of Marmara. Ann Ser Hist Nat 24: $41-46$

Martin CS, Vaz S, Ellis JR, Coppin F, Le Roy D, Carpentier A (2010) Spatio-temporal patterns in demersal elasmobranchs from trawl surveys in the eastern English Channel (1988-2008). Mar Ecol Prog Ser 417: 211-228

* Maxwell D, Jennings S (2005) Power of monitoring programmes to detect decline and recovery of rare and vulnerable fish. J Appl Ecol 42:25-37

McCully Phillips SR, Scott F, Ellis JR (2015) Having confidence in productivity susceptibility analyses: a method for underpinning scientific advice on skate stocks? Fish Res 171:87-100

* Meyers EK, Tuya F, Barker J, Jiménez Alvarado D, Castro Hernández JJ, Haroun R, Rödder D (2017) Population structure, distribution and habitat use of the Critically Endangered Angelshark, Squatina squatina, in the Canary Islands. Aquat Conserv 27:1133-1144

* Näslund J, Lundgren M (2018) Mapping the distribution of scale-rayed wrasse Acantholabrus palloni in Swedish Skagerrak using angling records. PeerJ 6:e5900

OSPAR Commission (2010) Background document for angel shark Squatina squatina. OSPAR Biodiversity Series, Publication Number 471/2010

Psomadakis PN, Maio N, Vacchi M (2009) The chondrichthyan biodiversity in the Gulf of Naples (SW Italy, Tyrrhenian Sea): an historical overview. Cybium 33: 199-209

Quéro JC, Cendrero O (1996) Incidence de la pêche sur la biodiversité ichtyologique marine: le bassin d'Arcachon et le plateau continental sud Gascogne. Cybium 20: 323-356

Rogers SI, Ellis JR (2000) Changes in the demersal fish assemblages of British coastal waters during the 20th century. ICES J Mar Sci 57:866-881

Roux C (1984) Squatinidae. In: Whitehead PJP et al. (eds) Fishes of the north-eastern Atlantic and the Mediterranean, Vol I. UNESCO, Paris, p 148-150

Serra-Pereira B, Erzini K, Maia C, Figueiredo I (2014) Identification of potential essential fish habitats for skates based on fishers' knowledge. Environ Manage 53: 985-998

Shephard S, Gerritsen H, Kaiser MJ, Reid DG (2012) Spatial heterogeneity in fishing creates de facto refugia for endangered Celtic Sea elasmobranchs. PLOS ONE 7: e49307

* Stat M, John J, DiBattista JD, Newman SJ, Bunce M, Harvey ES (2019) Combined use of eDNA metabarcoding and video surveillance for the assessment of fish biodiversity. Conserv Biol 33:196-205

* Vögler R, Milessi AC, Quiñones RA (2008) Influence of environmental variables on the distribution of Squatina guggenheim (Chondrichthyes, Squatinidae) in the Argentine-Uruguayan Common Fishing Zone. Fish Res 91:212-221

Went AEJ (1978) The zoogeography of some fishes in Irish waters. Fishery Leaflet Number 93. Irish Department of Fisheries, Dublin

Submitted: November 1, 2018; Accepted: January 27, 2019

Proofs received from author(s): March 14, 2019 